\title{
EKONOMI MELAYU DALAM TATANAN EKONOMI ISLAM
}

\author{
Syahpawi \\ Dosen Ekonomi Islam Fakultas Syariah dan Ilmu Hukum UIN Suka Riau
}

\begin{abstract}
This article discuss Malay economics in Islam economics order, between of jejula (Arisan) skim, garden pawn skim, pedua skim, promise sales skim, jetty money sales skim (having deposit), installment sales skim and all. This study concludes all these study behavior of Malay chartered investment counsel becoming the culture based on to Islam chartered investment counsel. This caused that exercise of culture done by Malay public is not quit of conceited al-Qur'an and Hadis.
\end{abstract}

Keywords: Ekonomi Melayu, Tatanan Ekonomi Islam, Aktivitas Budaya Melayu

\section{Pendahuluan}

Tulisan ini membicarakan tentang beberapa aktivitas ekonomi budaya melayu sebagai tatanan ekonomi Islam yang telah ada. Budaya melayu sebagai aktivitas ekonomi yang telah dilakukan dan berlaku dari sejak dulunya dapat dikembangkan kembali karena ia merupakan tatanan dari ekonomi Islam. Di samping itu ekonomi melayu dapat dilaksanakan pada institusi-institusi keuangan dan perbankan yang diciptakan dari aktivitas budaya melayu yang berasal dari tatanan ekonomi Islam.

Budaya diartikan sebagai cara berfikir, berkelakuan dan lain-lain. ${ }^{1}$ Perbuatan ekonomi yang dilakukan oleh masyarakat melayu dapat dipertimbangkan kembali untuk dijadikan sebagai produk lembaga keuangan Islam yang maju dan terkini sehingga aktivitas ekonomi melayu tersebut dapat dijadikan sebagai penentu dan pesaing dalam era globalisasi ekonomi modern. Budaya-budaya yang telah dikenal dari dulunya perlu digali kembali sebagai khazanah budaya bangsa untuk dikemukakan dan dikembangkan dalam suatu bentuk aliran fiqh ekonomi yang modern. Hal ini dapat dilakukan berdasarkan kepada pemikiran (jitihad) yang sesuai dengan suasana dan keadaan serta tidak bertentangan dengan prinsip-prinsip syariah.

\section{Ekonomi Melayu Dalam Tatanan Ekonomi Islam}

Budaya melayu yang berkaitan dengan perbuatan ekonomi tersebut dapat dilihat dari beberapa aktivitas ekonomi yang telah terjadi dari dulunya hingga sekarang masih berlangsung. Perbuatan tersebut masih wujud dalam kehidupan masyarakat budaya melayu yang dapat dilihat dalam beberapa

1 Departemen Pendidikan dan Kebudayaan, Kamus Besar Bahasa Indonesia. (Jakarta: Balai Pustaka, 1990), hlm. 130; Enciklopedi Indonesia, Edisi Khusus. Jakarta: Ichtiar Baru, hlm. 531. 
aktivitas ekonomi yang akan dikemukan dalam pembahasan ini. Aktivitas ekonomi dalam kebudayaan melayu dapat dijadikan sebagai produk-produk keuangan Islam dan oleh institusi-institusi perbankan yang ada. Ada beberapa aktivitas ekonomi melayu yang telah menjadi budaya dalam tatanan ekonomi Islam dapat dilihat, diantaranya adalah:

\section{a. Permainan Jejula (Arisan)}

Jejula atau permainan jejula dikenal oleh masyarakat melayu di kawasan Riau, terutama di Riau kepulauan. Sedangkan di Riau daratan istilah ini lebih dikenal dengan sebutan Julojulo, perkembangan berikutnya pada kalangan masyarakat melayu modern istilah ini lebih dikenal dengan sebutan Arisan. ${ }^{2}$ Di Malaysia permainan ini dikenal dengan istilah permainan Kutu. ${ }^{3}$ Jejula apapun istilahnya yang seumpama dengan hal tersebut didefenisikan sebagai perkumpulan yang mengumpul uang pada waktu tertentu (minggu, bulan dan tahun) dan menentukan giliran untuk mendapatkan penerimaan uang dengan cara mengundi. ${ }^{4}$ Miskipun tidak ada kenyataan yang jelas tentang jenis akad yang dilaksanakan, tetapi dapat dikatakan bahwa pada pelaksaannya akad wadi'ah (titipan) sudah terwujud yang digunakan oleh anggota yang ikut serta dengan kegiatan tersebut yaitu pada waktu menyerahkan uang jejula kepada ketua kumpulan yang dilantik.

Aktivitas permainan jejula ini telah menjadi budaya dikalangan masyarakat dikenal dengan ekonomi melayu, ini bertujuan untuk melakukan kegiatan tolong-menolong dan kerjasama diantara sesama anggota masyarakat dalam mengatasi masalah keuangan dan untuk mendapatkan modal dalam jumlah tertentu tanpa perlu pergi ketempat instansi keuangan dan perbankan. Jumlah dana yang terkumpul dalam satu pusingan tersebut tergantung kepada persetujuan masing-masing anggota dan latarbelakang pekerjaan dan keuangan mereka. Uang yang mereka peroleh dari permainan jejula tersebut kebanyakannya digunakan untuk mengembangkan usaha. Dalam sudut pandang yang lain aktivitas seperti ini adalah untuk mengelakkan orang-orang Islam dari praktek riba yang dilakukan oleh perbankan konvensional dengan menggunakan bunga untuk mendapatkan pinjaman modal.

Daripada itu pelaksanaan permainan jejula ini juga, jika dikembangkan kedalam produk keuangan dan perbankan dalam bentuk pembiayaan modal dengan menggunakan Formula yang baru dan merubah sistem dalam bentuk pelaksanaannya untuk menolong masyarakat miskin sangat mungkin dilakukan.

2 Arisan adalah pengumpulan uang atau barang yang bernilai sama oleh beberapa orang kemudian di undi diantara mereka untuk menentukan siapa yang memperoleh undian pertama, dilaksanakan secara berkala sampai semua anggota memperolehnya. Lihat, Departemen Pendidikan dan Kebudayaan, Ibid., hlm. 48.

3 Joni Tamkin Borhan, "Pengaruh Budaya Dalam Menentukan Hukum Muamalat", Seminar Hukum Islam Semasa III Peringkat Kebangsaan. Jabatan Fiqh dan Usul, Akademi Pengajian Islam, Universiti Malaya, 7 \& 8 November 2000.

${ }^{4}$ Joni Tamkin Borhan, Ibid. 
Pembiayaan modal yang bisa dilakukan adalah dalam bentuk Qard Hasan (Pinjaman Kebajikan) dengan memadukan aktivitas ekonomi melayu yang telah terjadi (jejula), sehingga Qard Hasan pada mulanya adalah pembiayaan dalam bentuk Kunsumtif berubah menjadi pembiayaan dalam bentuk produktif yang sangat dibutuhkan pada saat ini.

Dalam sistem pembiayaan produktif dalam bentuk Qard Hasan ini dengan memadukan jejula sebagai aktivitas ekonomi melayu sangat tepat digunakan untuk membantu masyarakat miskin didaerah perkampungan dan perdesaan bagi daerah-daerah tertinggal yang sangat memerlukan modal dalam pengembangan usaha mereka. Perpaduan diantara kedua bentuk tersebut dengan merubah pada sistem pelaksanaannya, dimana anggota masyarakat yang terlibat di dalamnya dijadikan dalam satu bentuk modal usaha, sehingga seluruh jumlah bagian masing-masing modal yang diperlukan dapat dikeluarkan sekaligus secara keseluruhannya sebanyak jumlah anggota masyarakat dan masa yang digunakan dalam tempo yang ditentukan (1 tahun) untuk dijadikan satu modal usaha bersama. Hal ini tidak terlepas dari keikutsertaan pemerintah (lurah, camat dan sebagainya) dalam kegiatan ini sebagai penjamin (kafalab bin-nafs) terhadap pengembalian modal yang dikeluarkan oleh lembaga keuangan.

Sebagai contoh anggota jejula/arisan 50 orang, masing-masing anggota membayar Rp 15.000 / minggu, maka satu bulan masing-masing anggota membayar Rp 15.000 × $4=\mathrm{Rp}$ 60.000. Jumlah anggota arisan 50 orang maka dalam satu bulan sudah menghasilkan Rp 60.000 x $50=$ Rp 3.000.000, Disebabkan pembiayaan Qard Hasan adalah pembiayaan dalam jangka pendek tidak melebihi dari satu tahun maka Rp 3.000.000 x 12 bulan = Rp 36.000.000, inilah yang harus dikeluarkan oleh lembaga keuangan sekaligus yang dapat dijadikan sebagai modal usaha bukan untuk konsuntif tetapi untuk produktif. Anggota hanya membayar/menyetor seperti biasa kepada bank sebagai titipan sesuai dengan kontrak jejula/arisan (Wadiab). Sedangkan pembiayaan yang diberikan oleh bank kepada persatuan jejula/arisan sekaligus inilah yang disebut dengan Qard Hasan.

Jika perpaduan ini dilakukan maka pelaksanaan Qard Hasan bukan lagi dalam bentuk pembiayaan konsumtif tetapi berubah menjadi pembiayaan produktif, ini tidak terlepas dari semangat dan keinginan masing-masing anggota dalam mengembangkan usaha demi untuk memajukan usaha dan meningkatkan tarap perekonomian masyarakat dalam mengembangkan nilainilai keusahawan. Semangat dari masing-masing anggota dalam

5 Qard al-hasan atau dalam istilah perbankan disebut juga dengan benevolent loan merupakan pinjaman lunak yang diberikan atas dasar kewajiban sosial/tolong-menolong semata di mana si peminjam tidak dituntut apapun selain dari pengembalian modal pinjaman. Lihat juga, Mohammad Hashim Kamali, Freedom, Equality, and Justice in Islam, (Selangor: Ilmiah Publisher, 1999), hlm. 191. 
mengembangkan usaha tersebut lebih dikenal dengan istilah semangat keusahawan yang tinggi dari masing-masing anggota.

Apabila aktivitas ekonomi budaya melayu dengan mengabungkan konsep-konsep syariah dapat dijalankan secara baik dan sempurna oleh lembaga keuangan dan para pihak yang terkait, maka ini akan dapat mengangkat masyarakat miskin untuk merubah strata perekonomian menjadi masyarakat yang maju dan berhasil dalam pembangunan ekonomi kedepan.

\section{b. Pajak / Gadai Kebun ${ }^{6}$ (Ar-Rahn)}

Gadai adalah apabila sesuatu barang yang berharga yang menjadi jaminan atau sandaran utang dan barang itu boleh dijualbelikan untuk menebus jumlah utang yang tidak dapat diselesaikan dan sisanya dikembalikan kepada pemilik asal barang. ${ }^{7}$ Pajak/Gadai Kebun $(A r$-Rahn) ini dilakukan oleh masyarakat Riau kepulauan dan Riau daratan, biasanya dilakukan pada perkebunan getah, sagu, kelapa, sawah dan sebagainya. Kegiatan ini lakukan dalam keadaan terpaksa. Ini merupakan jalan yang mudah dan mengelakkan dari pada riba untuk memperoleh uang (modal) bagi keperluan yang mendesak untuk pendidikan anak-anak mereka. Bentuk pelaksanaannya dimana masyarakat yang membutuhkan uang dengan cepat, mereka mendatangi tauke, kebun tersebut untuk dipajak/gadai dalam masa tertentu (2, 5, 10 tahun) sesuai dengan kesepakatan, biasanya kebun yang digadai tersebut sudah mendatangkan hasil, dalam masa tempo tersebut tauke yang memberi pinjaman uang (modal) berhak untuk menggunakan dan memperoleh hasil atas kebun yang telah digadai/dipajak. Jika masa tersebut berakhir maka kebun tersebut akan kembali kepada tuan yang punya kebun.

Sebagai contoh Si A mempunyai sebidang kebun sagu yang sudah menghasilkan, menurut kebiasaannya kebun tersebut sudah bisa ditebang kembali dalam masa tiga tahun lagi diperkirakan dapat menghasilkan 100 batang dengan jumlah Rp 10.000.000, namun Si A pada saat ini sangat memerlukan uang untuk keperluaan sekolah anaknya, maka Si A pergi menjumpai tauke sagu untuk mengadaikan / pajak kebun. Maka tauke sagu menyetujuinya setelah melihat kondisi kebun tersebut dengan memberikan pinjaman kepada Si A sebanyak yang dia inginkan dalam masa tempo (3, 5, 10 tahun) sesuai dengan kesepakatan. Selama masa tempo yang di gadai/pajak kebun tersebut, tauke yang memberikan pinjaman kepada Si A mengambil hasil dari kebunnya, kemudian apabila masa tempo berakhir maka diantara para pihak menghitungkan kembali berapa jumlah yang dihasilkan dari kebun yang berada ditangan tauke selama tempo tersebut dan berapa kekurangannya

6 Kedua istilah ini disamakan oleh masyarakat yang melakukan pergadaian/pajak kebun, miskipun istilah ini pada dasarnya berbeda pengertiannya secara mendalam, namun penulis menggunakan kedua istilah ini dalam satu makna. Ini disebabkan oleh kedua istilah ini disamakan oleh masyarakat yang melakukan kegiatan ekonomi tersebut.

7 Joni Tamkin Borhan, "Falsafah Ekonomi dan Instrumen Ekonomi dalam Amalan Perbankan Islam di Malaysia", Jurnal Syariah. (Universiti Malaya: Jabatan Syariah dan Ekonomi), hlm. 137. 
atas pinjaman yang diberikan. Jika terjadi kekurangan dari jumlah pinjaman maka dianggap sebagai utang dan sebaliknya jika ada kelebihan maka akan dibayar oleh tauke kepada Si A.

Dalam tatanan ekonomi Islam pelaksanaan seperti ini dikenal dengan istilah $A r-R a b n .^{8} A r-R a b n$ adalah menahan salah satu milik si peminjam sebagai jaminan atas pinjaman yang diterima. Barang yang diterima tersebut haruslah bernilai ekonomis. Ini dapat dikatakan bahwa pihak yang menahan dapat memperoleh jaminan atas modal yang diberikan kepada peminjam. Perjanjian gadaian merupakan satu langkah maju bagi menyakinkan para pihak dalam melakukan akad tersebut. Pelaksanaan pergadaian yang dilakukan oleh masyarakat di kampung-kampung dapat diterapkan dalam sistem keuangan dan perbankan dengan merubah bentuk pelaksanaan pergadaian yang telah ada dilakukan selama ini, dimana barang yang digadai tidak digunakan hanya bersifat jaminan. Namun pergadaian yang dilakukan oleh masyarakat yang telah menjadi budaya tersebut, dimana barang yang digadai dapat dimanfaatkan oleh si penerima gadaian. Penekanannya adalah barang yang digadai tersebut haruslah barang yang dapat dimanfaatkan sesuai dengan uang yang diambil sebagai bayaran terhadap barang yang diambil menfaatnya. Pemikiran seperti ini akan membuka peluang bagi masyarakat dalam memerlukan biaya pendidikan anak-anak mereka yang sangat memerlukan pendidikan yang merupakan nafkah dalam bentuk rohani yang wajib dipenuhi oleh masingmasing orang tua dan sangat tepat apabila diterapkan dalam perbankan Islam.

\section{c. Sistem Perdua9 (Perdua Haiwan atau Tanah)}

Di dalam kamus perkataan perdua ${ }^{10}$ diartikan sebagai membagi dua dari hasil yang akan diperoleh dalam usaha tanah perkebunan, binatang ternak yang telah ditentukan diantara pengusaha dengan pemiliknya. Istilah perdua ini digunakan pada masyarakat melayu yang berada di daerah Riau kepulauan dan pesisir, namun pada melayu serumpun seperti Malaysia istilah perdua lebih kenal dengan sebutan pawah. ${ }^{11}$ Dimana pelaksanaan sistem pawah yang dilaksanakan di Malaysia diberikan pada perkebunan, tanah dan hewan ternak. Hal ini juga berlaku di daerah Melayu Riau. Dalam sistem pawah hewan yang telah dikomersialkan oleh jabatan hewan (Veterinary Department) diartikan sebagai skim pinjaman hewan betina. ${ }^{12}$ Pawah dan perdua dalam pengertian yang umum dan luas lebih kenal dengan istilah pinjaman (loan). ${ }^{13}$

${ }^{8}$ Ibn Abidin, Hasyizah Ibn Abidin, Vol. V. (Beirut: Dar al-Fikr, tt), hlm. 339; alSarakhsi, Al-Mabsuti, Vol. XXI. (Beirut: Dar al-Fikr, 1982), hlm. 63.

${ }^{9}$ Keterangan dari judul ini berdasarkan kepada observasi dan temubual yang penulis lakukan secara informal saja, makanya istilah tersebut kental dengan bahasa melayunya.

${ }^{10}$ Kaти Bahasa Indonesia.

${ }^{11}$ Kamus Dewan, (Kuala Lumpur, Dewan Bahasa dan Pustaka,1989), hlm. 922.

12 Misalnya kerbau, kambing, dan lembu diberikan oleh jabatan hewan kepada peternak dan kemudian perternak akan mengembalikan hewan yang sama jantina dan umurnya kepada jabatan hewan tersebut. Skim ini berlaku setelah hewan betina yang dipawah itu melahirkan anak, dan anak inilah yang akan dipulangkan kepada jabatan hewan 
Pelaksanaan sistem ini bertujuan untuk menambah jumlah binatang peliharaan serta untuk memperbaiki strata kehidupan ekonomi masyarakat yang berada pada perdesaan dan perkampungan. ${ }^{14}$ Aktivitas ekonomi melayu ini bertujuan untuk membantu anggota masyarakat yang tidak mempunyai modal dalam mengembangkan usaha mereka baik yang berhubungan dengan binatang ternak maupun perkebunan dan sawah ladang serta untuk meningkatkan tarap ekonomi masyarakat. Pelaksanaan ini dilakukan dimana pada masa yang sama pihak pemodal atau pemilik binatang akan memiliki binatang yang diperdua tersebut setelah masa tempo tertentu, yaitu sampai binatang tersebut melahirkan anak dan dalam umur yang sama.

Ekonomi Islam memandang akad seperti ini dapat dilihat sama seperti dengan akad mudharabah yaitu pemilik binatang asal adalah sebagai pemodal (Sleeping partner/Shabib al-mal) dan penerima perdua adalah pengusaha (entrepreneur/Mudharib) bersepakat untuk melakukan kerjasama dengan kesepakatan dimana baka binatang akan menjadi milik pengusaha apabila anak yang dilahirkan oleh binatang tersebut telah mencapai umur tertentu dan dikembalikan kepada pemilik modal. Secara tidak langsung bagi mereka yang mempunyai daya usaha dan semangat yang tinggi untuk maju dalam bidang ekonomi tetapi tidak mempunyai modal, dapat diberi kesempatan untuk membangun dan mengembangkan Industri Perternakan dan dapat mengurangi ketergantungan kepada negara-negara luar yang sudah dikenal dalam usaha industri tersebut.

Begitu juga halnya dalam bentuk pertanian dan perkebunan sistem perdua dilakukan oleh para petani yang tidak mempunyai tanah. Diamana para petani akan memperdua tanah dengan tuan yang mempunyai tanah baik itu dalam bentuk padi, kelapa, kelapa sawit dan sebagainya dari hasil pertanian yang diperoleh tersebut akan dibagikan kepada pemiliknya sesuai dengan perjanjian yang disepakti. Misalnya dari seluruh hasil pertanian sebagian dibagikan kepada pemiliknya dan sebagian lagi kepada pengusaha petani. Tempo perdua ini akan berakhir apabila hasil untuk satu musin telah dipungut atau batas tempo tertentu yang telah dipersetujui itu terpenuhi. Aktivitas ekonomi budaya melayu ini dilakukan dengan tujuan untuk menghindari para petani yang tidak mempunyai modal dari aktivitas pinjaman kepada bank-bank konvensional yang menggunakan sistem bunga cendrung kepada riba, serta memberatkan bagi petani untuk membayar hutang apabila terjadinya pinjaman.

Bagi para petani yang miskin yang berada dalam keadaan yang tidak baik apabila terjadi pinjaman kepada bank konvensional, mereka terpaksa untuk membayar pinjaman hutang mereka meskipun hasil dari perkebunan dan

sebagai ganti daripada baka yang asal. Lihat, Joni Tamkin Borhan, Falsafah Ekonomi....., hlm. 7.

${ }^{13}$ Kamus Bahasa Inggris. Dalam bahasa Belanda Istilah ini lebih dikenal dengan "Lenen".

${ }^{14}$ Justin K. Camoens, The Pawah Sistem in East Pabang. (Ministry of Agriculture and Lands, 1971), hlm. 2. 
pertanian mereka tidak menjadi atau memperoleh hasil yang sedikit. Namun berbeda halnya dengan sistem perdua ini, dimana para petani hanya perlu membayar sesuai dengan hasil yang mereka peroleh, baik hasil panennya melimpah maupun sedikit. Dalam persoalan perdua ini, yang perlu dibayar atau dibagikan antara kedua belah pihak adalah kadar ratio daripada hasil pertanian dan perkebunan yang diperoleh, bukan satu jumlah yang tetap.

Aktivitas ekonomi melayu sebagai budaya yang berhubungan dengan pelaksanaan perdua ini, perlu dikembangkan dan ketetengahkan serta diterapkan baik itu melalui instansi pemerintah maupun swasta, apalagi kepada lembaga-lembaga keuangan sangat diharapkan menerapkan sistem ini dalam membantu masyarakat diperdesaan dan diperkampungan.

\section{d. Jual Janji (Bay al-Wafa')}

Jual janji (conditional sale) adalah perbuatan ekonomi dalam kebudayaan melayu, terutama dikalangan masyarakat yang berada didaerah Riau kepulauan, pesisir dan Riau daratan yang melakukan kegiatan tersebut. Perbuatan ini telah dilakukan semenjak pemerintah kerjaan berdaulah berlangsung dan sebelum zaman penjajahan lagi. Aktivitas budaya melayu (jual janji) ini telah terjadi dan diketengahkan serta menjadi kebiasaan bagi masyarakat pada masa dulunya sampai sekarang aktivitas tersebut masih berlaku.

Dalam bahasa fiqh jual janji ini lebih dikenal dengan istilah Bay al-Wafa'. Dari segi bahasa Al-Bay' berarti jual beli dan al-wafa' berarti pelunasan atau penyelesaian hutang. Para ulama fiqh telah mengartikan sebagai salah satu jual beli yang dilakukan oleh dua pihak dengan mensyaratkan bahwa barang yang diakadkan tersebut dapat dibeli kembali oleh penjual apabila masa temponya berakhir dengan bersetujuan kedua belah pihak yang berakad. ${ }^{15}$ Bentuk ini dilakukan adalah untuk mendapatkan modal dalam usaha pembuatan kebun dan seumpama dengan kebun serta bermacam-macam penanaman perkebunan lainnya tanpa perlu menjumpai instutusi yang memeras (Lintah darat/tangkulak). Hal ini dilakukan untuk menghindari dari perbuatan atau praktek-praktek tangkulak atau lintah darat yang penuh dengan riba dan tipu helah yang terjadi pada masa tersebut. ${ }^{16}$

Pelaksanaan akad ini juga banyak dilakukan oleh penduduk di Asia Tenggah (Bukhara) pada pertengahan abad ke $5 \mathrm{H}$ untuk menghindari daripada perbuatan pinjaman yang menglibatkan unsur-unsur riba, dan hal ini juga dilakukan oleh masyarakat timur tenggah pada masa kemudiannya. ${ }^{17}$ Akad yang menjadi budaya melayu yang merupakan perbuatan ekonomi dilakukan

15 Al-Zarqa, Sharh al-Qanun al-Suri: al'Uqud al-Musammahlm. (Damsyiq: Dar al-Kitab, 1968), hlm. 23; al-Mausu'ah al-Fiqbiyyah, J, 9. (Kuwait: tp, 1987), hlm. 48-49.

16 W. E. Maxell, "The Law and The Customs of the Malays with Reference to the Tenure of Land", Journal of the Straits Branch of The Royal Asiatic Society, No. XIII, June 1884, hlm. 123; Cf. M. B. Hooker, Reading in Malay Adats Laws. (Singapore: tp, 1970), hlm. 354-361; J. M. Gullick, Malay Society in the Late Nineteenth Century. (Singapore: tp, 1987), hlm. 98-149.

17 'Abd al-Rahman al-Sabuni, al-Madkhal li Dirasah al-Tasyri' al-Islami, J. I. (Damsyiq: Matba’ah al-Riyad, 1980), hlm. 64. 
dengan tujuan untuk mendapatkan kemudahan kredit tanpa terlibat dengan perbuatan (amalan) riba. Akad ini biasa dilakukan oleh masyarakat melayu dalam bentuk penjualan tanah atau harta tetap milik penjual kepada pembeli dengan janji untuk membeli semula tanah tersebut dalam tempo tertentu (misalnya 2-3 tahun). Dalam masa tempo itu pembeli boleh menggunakan dan menduduki tanah tersebut. Jika masa tempo yang dijanjikan tersebut penjual gagal untuk membeli semula hartanya, maka ia akan berpindah kepada si pembeli dan harta tersebut menjadi milik si pembeli. ${ }^{18}$

Akad jual beli ini merupakan budaya melayu yang terjadi pada masa dulunya dan telah mendapat perhatian khusus dalam perundangan oleh hakimhakim di Inggris. ${ }^{19}$ Budaya Melayu ini perlu untuk dikembangkan dan dapat ditawarkan kepada institusi keuangan dan perbankan agar dijadikan sebagai salah satu produk perbankan Islam dalam bentuk pembiayaan modal. Adapun sebagai sasaran dari produk ini adalah masyarakat petani kecil dalam mengusahakan penanaman padi, kelapa, kelapa sawit, sayur-sayuran dan sebagainya yang berada dipedesaan, dimana masyarakat pedesaan tersebut sukar untuk mendapatkan modal daripada sumber yang lain. Pemerintah perlu juga memperkirakan masalah ini untuk dijadikan sebagai salah satu bentuk pembiayaan yang dilakukan baik itu pada Dinas Perkebunan, Pertanian, dan sebagainya.

\section{e. Jual Beli Berdeposit/Uang Pangkal (Bay’al-'Arbun) ${ }^{20}$}

Akad jual beli seperti ini merupakan bebarapa akad ekonomi yang telah terjadi dan menjadi kebiasaan masyarakat melayu dan sampai sekarang pun masih berlaku dan mudah-mudahan terus berlaku. Dalam tatanan ekonomi Islam (figh muamalah), akad bentuk ini dikenal dengan Bay' al-'Arbun, dalam bahasa Arab berarti pembeli membayar uang pendahuluan. Dari segi istilah kata Bay' al-'Arbun dapat diartikan sebagai suatu akad jualbeli yang dilakukan dengan suatu pembayaran pendahuluan pada suatu harga barang, dimana pembayaran uang pangkal atau deposit tersebut merupakan bagian dari jumlah uang yang harus dibayar secara keseluruhannya oleh pembeli sekiranya jual beli itu diteruskan. Sebaliknya jika pembeli membatalkan akad tersebut, maka uang

\footnotetext{
18 Saleh Buang, "Ke Arah Pengislaman Kanun Tanah Negara" dalam Fakulti Undangundang Universiti Malaya, Makalah Undang-undang Menghormati Abmad Ibrabim. (Kuala Lumpur: DBP, 1988), hlm. 175-176.

19 Antara lain dalam perkara Tengku Zahara Lawan Che Yusuf (1951 MLJ I), Hakim Briggs memutuskan bahwa tujuan transaksi jual janji ialah untuk mendapatkan kemudahan kredit (hutang) dan memberikan kepada pemberi pinjaman (pembeli tanah) bayaran gantirugi yang setimpal, tanpa terlibat dangan amalan bunga (usury) dimana orang-orang Islam dilarang terlibat untuk melakukannya, Lihat. Norhashimah Mohd. Yasin, Islamization/Malaynization: A Study of the Role of Islamic Law in the Economic Development of Malaysia: 1969-1993. (Kuala Lumpur: tp, 1996), hlm. 264. 59.

20 Ahmad Al-Sharbasi, Al-Mu'jam al-Iqtisadi al-Islami. (Istambul: Dar al-Jayl, 1981), hlm.
} 
pangkal tersebut menjadi milik penjual dan tidak akan dikembalikan lagi kepada si pembeli miskipun si pembeli meminta kembali uang pangkalnya. ${ }^{21}$

Para fuqaha mendefenisikan jual beli seperti ini adalah pembelian yang dilakukan tanpa membayar semua harganya, namun pembeli hanya membayar sejumlah uang sebagai pendahuluan saja sedangkan sisanya akan dibayar kemudian apabila pembeli ingin meneruskan akad tersebut. ${ }^{22}$ Dengan kata lain, sekiranya pembeli bersetuju meneruskan akad tersebut maka uang pangkal ini dianggap sebagai bagian dari jumlah uang terhadap harga barang yang dijual, dan sekiranya pembeli membatalkan akad jual beli tersebut, maka uang tersebut dianggap hangus dan menjadi milik penjual. Pendapat ini dibenarkan oleh para fuqha berdasarkan hadis-hadis Rasulullah saw dan amalan para Sahabat. Sebagaimana hadis yang diriwayatkan oleh Zayd bin Aslam yang bertanya kepada baginda Rasulullah saw tentang Bay' al-'Arbun dan baginda meneruskannya. ${ }^{23}$ Sebuah hadis Shahih yang terdapat di dalam Shahih AlBukhari yang artinya:

"Diriwayatkan dari Ibn 'Aun dari Ibn Sirin katanya: Seorang penyewa berkata kepada tuan punya binatang tunggangan yang bakal disewanya: "siapakah binatang tunggangan kamu, sekiranya saya tidak jadi menyewa binatang itu pada hari sekian (tertentu), maka bagimu bayaran ganti rugi 100 dirham”, ternyata kemudiannya penyewa tadi tidak jadi bertolak, maka menurut shurayh: "Barangsiapa yang membuat syarat ke atas dirinya secara sukarela tanpa paksaan, maka syarat tersebut adalah terpakai". 24

Ibn Qayyim telah mengharuskan akad ini berdasarkan hadis tersebut, dimana sebagai alat bukti yang harus dilakukan untuk mengambil bayaran tertentu dalam satu akad yang diakibatkan oleh menunggu atau tergendalanya suatu kegiatan ekonomi. ${ }^{25}$ Selain daripada itu akad ini bertujuan untuk memastikan pembeli tersebut apakah benar-benar serius dalam akadnya atau tidak, sebagai bayaran ganti rugi yang ditanggung oleh penjual dalam tempo menunggu jika pembeli tidak meneruskan akadnya adalah uang pangkal tersebut sebagai gantinya. ${ }^{26}$

Kemudian para fuqaha juga berpegang kepada amalan para sahabat Rasulullah saw yang diriwayatkan oleh Nafi' bin al-Harith, beliau telah membelikan Syaidina Umar al-Khatab sebuah rumah dari Safwan bin Umayyah untuk dijadikan penjara dengan harga 4 ribu dirham. Dalam jual beli

21 Ibn Rusyd, Bidayatul al-Mutahid wa Nihayah al-Muqtasid, J. 2. (Beirut: Dar al-Fikr, tt), hlm. 122; Ibn Qudamah, Al-Mughni. (Beirut: tp, 1984), hlm. 313; Md. Nurdin Hj. Ngadimon, "Jual Beli Berdeposit: Satu Penilaian Fiqh", Jurnal Syariah, J. 2, Juli 1994, hlm. 72.

22 Ibn Rusyd, Bidayatul ...., hlm. 122.

${ }^{23}$ Ibn Hajar al-'Asqalani, Talkhis al-Hibr, J. 3. (Madinah, tp, 1964), hlm. 17; Wahbah alZuhaili, al-Figh al-Islami wa Adillatuh, J. 4. (Beirut: Dar al-Fikr, 1989), hlm. 449-450.

${ }_{24}$ Al-Bukhari, Shahih al-Bukhari, J. 3. (Beirut: Dar al-Fikr, 1991), hlm. 234. hlm. 400

25 Ibn Qayyim, A'lam al-Muwaqqin 'an Rabb al-'Alamin, J. 3. (Beirut: Dar al-Fikr, t.t), ${ }^{26}$ al-Zarqa, Al-Madkhal al-Fiqh al-'Am, J. 1. (Damsyiq: Dar al-Fikr, 1968), hlm. 459 
ini disyaratkan jika sekiranya Syaidina Umar tidak setuju dengan jual beli ini, maka Safwan selaku penjual akan mendapat 400 dirham. ${ }^{27}$ Berdasarkan kepada dailil tersebut diatas maka dapat dikatakan bahwa pelaksanaan jual beli berdeposit/Uang pangkal adalah sah dalam pandangan Islam.

Dalam kegiatan ekonomi masa kini, akad seperti ini amat penting dilakukan untuk menjaga kepentingan para pihak yang melakukan akad terutama pihak penjual. Dimana penjual terbuka peluang kepada bahaya kerugian jika pembeli membatalkan akad tersebut. Adanya deposit/uang pangkal itu menjadi jaminan kepada penjual terhadap akad yang dilakukan. Akad ini tidak hanya berlaku pada jual beli, namun dapat juga diterapkan kepada sewa-menyewa dan lain-lain.

\section{f. Jual Beli Angsuran (Al-Bay'Bithaman Ajii)}

Jual beli angsuran adalah jual beli yang dilakukan secara angsuran atau lebih kenal dengan istilah jual beli kredit dalam kalangan masyarakat modern. Pelaksanaan jual beli angsuran ini sama halnya dengan jual beli kredit, dimana penjual menjualkan barang dagangannya kepada pembeli dengan pembayaran yang dilakukan secara beransur-ansur/cicilan. Dalam Islam jual beli yang dilakukan secara kredit/angsuran dalam jangka yang lama (5 tahun keatas) dikenal dengan istilah Al-Bay'Bithaman Ajil. Al-Bay'Bithaman Ajil adalah akad pembelian barang dengan pembayaran secara cicilan/angsuran. ${ }^{28}$

Perhatian utama yang perlu dilakukan dalam aktivitas ekonomi yang dilakukan oleh masyarakat melayu yang telah menjadi budaya tersebut adalah jual beli yang dilakukan tanpa menetapkan jumlah angsuran yang harus dibayar oleh pembeli kepada penjual. Pembayaran dilakukan oleh pembeli sesuai dengan kesanggupannya untuk membayar dalam istilah melayu lebih dikenal dengan sebutan "berape ada saje", tidak menjadi jumlah yang telah ditetapkan setiap pembayaran. Inilah yang menjadi perbedaan yang mendasar bila dibandingkan dengan pelaksanaan jual beli yang dilakukan secara kredit. Jika pembelian yang dilakukan secara kredit jumlah pembayarannya ditetapkan secara berkala setiap kali pembayaran.

Ini merupakan pelajaran yang menarik bagi kita semua, karena unsur tolong-menolong, bantu-membantu dalam bentuk kekeluargaan sangat jelas dilakukan oleh masyarakat melayu dalam aktivitas ekonomi yang telah menjadi budaya dari dulu sampai sekarang dituangkan dalam bentuk perdagangan. Bagi masyarakat yang miskin, terhadap pemberian pinjaman yang dilakukan oleh institusi keuangan dan pemerintah sangat mungkin untuk dikembangkan kepada mereka yang membutuhkan tersebut dengan menjalankan konsepkonsep budaya yang digali dari konsep-konsep syariah sebagai acuan dasar pada kegiatan ekonomi melayu. Para pengusaha yang melakukan praktek-

${ }^{27}$ Ibn Qudamah, Al-Mug........, hlm. 313

${ }^{28}$ Karnaen Perwataatmadja dan Muhammad Syafi'i Antonio, Apa dan Bagaimana Bank Islam. (Yogyakarta: Dana Bhakti Wakaf, 1992), hlm. 26. 
praktek budaya melayu tersebut tidak pernah mengalami kerugian malah untung yang mereka peroleh dari angsuran yang diterima tanpa menetapkan jumlah pembayaran dan mereka lebih merasakan keikhlasan dan keredhaan dari masing-masing pihak yang melakukan teransaksi tersebut.

\section{Kesimpulan}

Dari penjelasan di atas, budaya ('urf) yang dilakukan oleh masyarakat pada aktivitas ekonomi melayu dalam tatanan ekonomi Islam dapat dijadikan sebagai produk keuangan dan perbankan untuk memenuhi kebutuhan hidup masyarakat sehari-hari. Aktivitas ekonomi melayu ini tidaklah bertentangan dengan prinsip-prinsip syariah yang berlaku. Ini terbukti bahwa pelaksanaan seperti ini pernah dilakukan oleh masyarkat arab di awal kedatangan Islam. Kedatangan Islam kedunia tidak menghapus keseluruhan aktivitas ekonomi yang terjadi pada saat itu, malah aktivitas seperti itu dikembangkan menjadi suatu prinsip dalam perekonomian Islam, seperti wadi'ah, gadaian, sewaan, AlBay'Bithaman Ajil, Bay' al-'Arbun, Bay' al-Wafa' dan sebagainya. Sebenarnya masih banyak lagi aktivitas ekonomi melayu dalam tatanan ekonomi Islam yang dapat dijadikan sebagai dasar produk keuangan dan perbankan. Ini hanya marupakan sekelumit saja untuk memancing pertumbuhan pemikiran yang perlu dikembangkan ditengah-tengah masyarakat sebagai panduan didalam berekonomi. Pelaksanaan aktivitas ekonomi yang ada di dalam masyarakat melayu yang tidak bertentangan dengan prinsip-prinsip syariah tersebut perlu dikembangkan dengan tidak merasa keraguan untuk melakukannya. Selanjutnya diharapkan kepada pemikir-pemikir Islam dalam penyelesaian aktivitas ekonomi budaya yang terjadi di tengah-tengah masyarakat tersebut dapat diselesaikan tanpa terikat dari perbedaan para mazhab Islam, yang perlu diperhitungkan adalah keperluan dengan tidak bertentangan dengan prinsipprinsip syariah. Di samping itu, penjelasan ini dibuat untuk menyadarkan kepada perbankan dan institusi keuangan lainya baik itu pemerintah maupun swasta supaya menerapkan prinsip-prinsip yang telah ada itu dihidupkan dan dikembangkan menjadi formula baru sehingga dari tradisi yang khas dulunya menjadi penomena baru dalam menghadapi tantangan global dalam perekonomian tersebut. Untuk itu penerapan sistem syariah yang merupakan jawaban atas ketimpangan yang berlaku selama ini sangat perlu dilakukan. Para ulama, ahli ekonomi Islam dan para pengamat perbankan Islam, aktivitas ekonomi budaya melayu ini bisa dijadikan sebagai produk perbankan untuk membiayai proyek-proyek dan sebagainya dalam membutuhkan pembiayaan modal kecil dan besar; jangka pendek, menengah dan panjang, secara tidak langsung dapat membantu bagi para petani dan masyarakat yang berpotensi untuk mengembangkan usaha mereka menjadi mengusaha yang sukses dan berjaya.

\section{Bibliografi}


'Abd al-Rahman al-Sabuni, al-Madkhal li Dirasah al-Tasyri' al-Islami, J. I. (Damsyiq: Matba'ah al-Riyad, 1980).

Ungku Abdul Aziz, Pilgrims Economy Improvement Plan. Kuala Lumpur, kemudian dalam, Lembaga Urusan dan Tabungan Haji Sebagai Satu Institusi Pelaburan Islam. (Kuala Lumpur: tp. 1980)

Ahmad Al-Sharbasi, Al-Mu'jam al-Iqtisadi al-Islami. (Istambul: Dar al-Jayl, 1981).

Ibn Abidin, Hasyiyah Ibn Abidin, Vol. V. (Beirut: Dar al-Fikr, tt)

Ausaf Ahamad, "The Evolution of Islamic Banking" dalam Encyclopeadia of Islamic Banking And Insurance. (London: tp, 1995)

Azlan Khalili Shamsuddin, Banking and Public Finance in Islam. (Jakarta: Dewan Pustaka Fajar, 1988)

Ahmad, Khurshid, Studies in Islamic Economics. Leicester, (UK: The Islamic Foundation, 1980)

Arif, Muhammad, Monetary and Fiscal Economics of Islam. (Jeddah: International Centre for Research in Islamic Economics, 1982)

Al-Batriq, "Planning for Economic Development in an Islamic Framework", dalam Ilyas ba-Yunus (ed), Islam and Development. (Plainfield, Indiana: The Association of Muslim Social Scientists, 1977).

Baran, Paul, The Political Economy of Growth. (England: Penguin Edition, 1957).

, The Political Economy of neo-Colonialism. (London: Heinemann, 1975).

Boeke, J.H, "Economics and Economic Policy of Dual Societies", Three Form of Disintegration in Dual Societies, April 1954.

Bonne, Alfred, Studies in Economic Development. (London: Routledge and Kegan Paul, 1960).

Bulanadi, A, "An Ecological Study of A Development Organization: The Philippine Community Development Program from Its Inception to The Present (1956-1968)". (Dissertation, Claremont, 1970).

Burton, Henry J, Principles of Development Economics. (Englewood Cliffs: Prentice Hall Inc, 1965).

Al-Bukhari, Shahih al-Bukhari, J. 3. (Beirut: Dar al-Fikr, 1991)

Bank Ekonomi, Annual Report. (Jakarta: 1999)

Bank Indonesia, Petunjuk Pelaksanaan Pembukaan Kontor Bank Syariah. (Jakarta: Bank Indonesia, 1999) 
Cairncross, A.K, Factors in Economic Development. (London: George Allen \& Unwin Ltd, 1962)

Carter, Aidan Foster, The Sociology of Development. Rahimah Abdul Azis (Terj.). (Malaysia: Dewan Bahasa dan Kementerian Pendidikan, 1989)

Chapra, M. Umer, Islam and Economic Development. (Islamabad Pakistan: International Institute of Islamic Thought and Islamic Research Institute, 1993)

Islam and The Economic Challenge. (Herndon: The Islamic Foundation and The International Institute of Islamic Thought, 1995)

Departemen Pendidikan dan Kebudayaan, Kamus Besar Bahasa Indonesia. (Jakarta: Balai Pustaka, 1990) Pustaka, 1989)

Enciklopedi Indonesia, Edisi Khusus. (Jakarta: Ichtiar Baru, tt)

Economic Development of Malaysia: 1969-1993. (Kuala Lumpur: tp)

The New Encyclopeadla Britannica, Vol. I, (Chicago, 1985)

Ibn Hajar al-'Asqalani, Talkhis al-Hibr, J. 3. (Madinah: tp, 1964)

Cf. M. B. Hooker, Reading in Malay Adats Laws. (Singapore: tp, 1970)

Joni Tamkin Borhan, "Pengaruh Budaya Dalam Menentukan Hukum Muamalat", Seminar Hukum Islam Semasa III Peringkat Kebangsaan. Jabatan Fiqh dan Usul, (Akademi Pengajian Islam, Universiti Malaya, 7 \& 8 November 2000)

"Falsafah Ekonomi dan Instrumen Ekonomi dalam Amalan Perbankan Islam di Malaysia", Jurnal Syariah. (Universiti Malaya: Jabatan Syariah dan Ekonomi)

Justin K. Camoens, The Pawah Sistem in East Pahang. (Ministry of Agriculture and Lands, 1971)

J. M. Gullick, Malay Society in the Late Nineteenth Century. (Singapore: tp, 1987)

Karnaen Perwataatmadja dan Muhammad Syafi'i Antonio, Apa dan Bagaimana Bank Islam. (Yogyakarta: Dana Bhakti Wakaf, 1992)

Md. Nurdin Hj. Ngadimon, "Jual Beli Berdeposit: Satu Penilaian Fiqh”, Jurnal Syariah, J. 2, Juli 1994 
Muhammad Syukri Salleh (ed), Konsep dan Pelaksanaan Pembangunan

Berteraskan Islam. (KL: Universiti Sains Malaysia, 1990)

Muhammad Syafi'i Antonio, Islamic Banking. Terj. (Bank Syariah dari Teori ke Praktek). (Jakarta: Gema Insani, 2001)

Ab. Mumin Ab. Ghani, Sistem Keuangan Islam dan Pelaksanaannya di Malaysia. (Kuala Lumpur: Jabatan Kemajuan Islam Malaysia, 1999)

Mohammad Hashim Kamali, Freedom, Equality, and Justice in Islam, (Selangor: Ilmiah Publisher, 1999)

W. E. Maxell, "The Law and The Customs of the Malays with Reference to the Tenure of Land", Journal of the Straits Branch of The Royal Asiatic Society, No. XIII, June 1884

Norhashimah Mohd. Yasin, Islamization/Malaynization: A Study of the Role of Islamic Law in the. (Tesis, Kl: Universiti Malaya, 1996)

Ibn Qayyim, A'lam al-Muwaqqin 'an Rabb al-'Alamin, J. 3. (Beirut: Dar alFikr, t.t)

Ibn Qudamah, Al-Mughni. (Beirut: tp, 1984)

Quresyi, Anwar Iqbal, Islam and Theory of Interest. (Lahore: SH. Muhammad Ashraf, 1961)

Al-Rahman, Afzal, Economic Doctrines of Islam. (Lahore: Islamic Publication Ltd, 1985)

Ibn Rusyd, Bidayatul al-Mutahid wa Nihayah al-Muqtasid, J. 2. (Beirut: Dar al-Fikr, tt)

Rosli Mahmood, Konsep Dasar Perbankan. (Kuala Lumpur: DBP, 1994) dan; Kamus Perbankan. (Kuala Lumpur: DBP,1998)

R. K. Ready, "The Egyptian Municipal Savings Bank Project”, International Development Review. (Vol. IX (2), 1967)

Sudin Haron, Prinsip dan Operasi Perbankan Islam. (Kuala Lumpur: Berita Publishing, 1996)

al-Sarakhsi, Al-Mabsuti, Vol. XXI. (Beirut: Dar al-Fikr, 1982)

Saleh Buang, "Ke Arah Pengislaman Kanun Tanah Negara" dalam Fakulti Undang-undang Universiti Malaya, Makalah Undang-undang Menghormati Ahmad Ibrahim. (Kuala Lumpur: DBP, 1988)

Traute Wohler-Scharf, Arab and Islamic Banking, (Paris: Development Center of the organization for Economic Cooperation And Development, 1983) 
Wahbah al-Zuhaili, al-Fiqh al-Islami wa Adillatuh, J. 4. Beirut: Dar al-Fikr, 1989)

Al-Zarqa, Sharh al-Qanun al-Suri: al'Uqud al-Musammah. Damsyiq: Dar al-Kitab, h. 23; al-Mausu'ah al-Fiqhiyyah, J, 9. (Kuwait, tp, 1987)

al-Zarqa, Al-Madkhal al-Fiqh al-‘Am, J. 1. (Damsyiq: Dar al-Fikr, 1968) 